\title{
चUSes
}

science for a changing world

U.S. DEPARTMENT OF THE INTERIOR

U.S. GEOLOGICAL SURVEY

\section{Preliminary Report on Geophysics of the Verde River headwaters region, Arizona}

by V.E. Langenheim ${ }^{1}$, J.S. Duval ${ }^{2}$, Laurie Wirt ${ }^{3}$, and Ed Dewitt ${ }^{3}$ Open-File Report 00-403

2000

This report is preliminary and has not been reviewed for conformity with U.S. Geological Survey editorial standards or with the North American Stratigraphic Code. Any use of trade, firm, or product names is for descriptive purposes only and does not imply endorsement by the U.S. Government.

The Arizona Water Protection Fund Commission has funded all or a portion of this report. The views or findings represented in this deliverable are the Grantees and do not necessarily represent those of the Commission nor the Arizona Department of Water Resources.

\section{U.S. DEPARTMENT OF THE INTERIOR}

\section{U.S. GEOLOGICAL SURVEY}

${ }^{1}$ Menlo Park, California

${ }^{2}$ Reston, Virginia

${ }^{3}$ Denver, Colorado 


\section{TABLE OF CONTENTS}

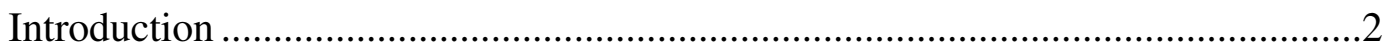

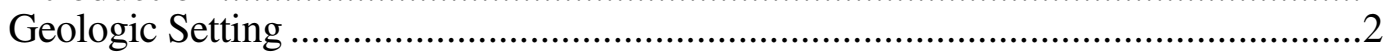

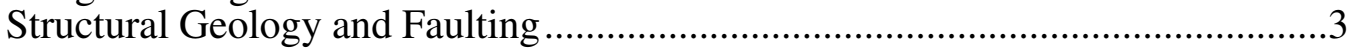

Aeromagnetic Data, Maps, and Derivative Products ......................................... 4

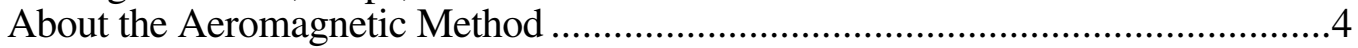

Magnetic Lithologies ..................................................................................

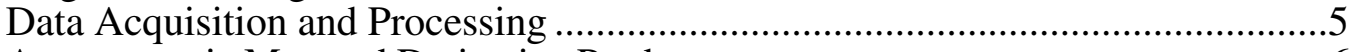

Aeromagnetic Map and Derivative Products ......................................................6

Radiometric Data and Maps...............................................................................

About the Gamma-Ray Method ......................................................................

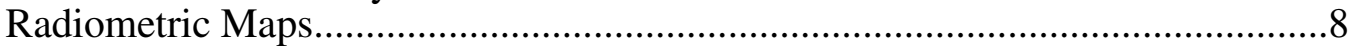

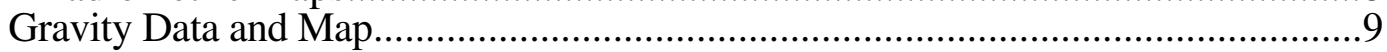

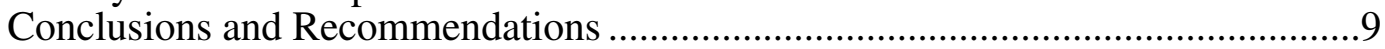

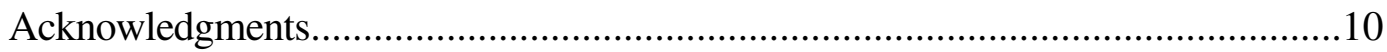

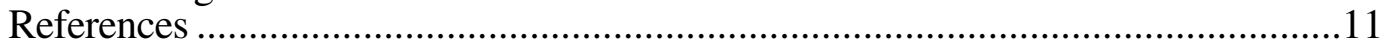

\section{FIGURES}

Figure 1. Shaded-relief topographic map of the study area.................................13

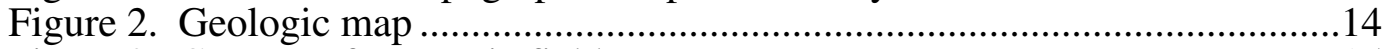

Figure 3. Cartoon of magnetic field .............................................................15

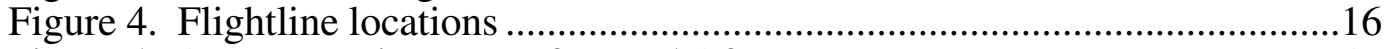

Figure 5. Aeromagnetic Map Before and After.................................................17

Figure 6. Closer view of aeromagnetic data.........................................................19

Figure 7. Filtered ("residual") aeromagnetic data ..........................................20

Figure 8. Magnetization boundaries................................................................21

Figure 9. Magnetization boundaries on geologic map......................................22

Figure 10. Area measured by an airborne gamma-ray spectrometer.......................23

Figure 11. Distribution of uranium ...............................................................24

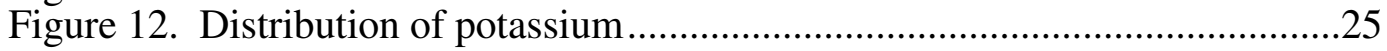

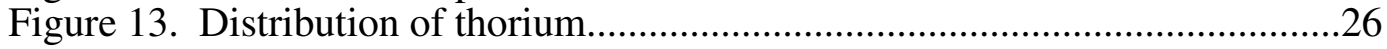

Figure 14. Color composite map of uranium, potassium, and thorium ...................27

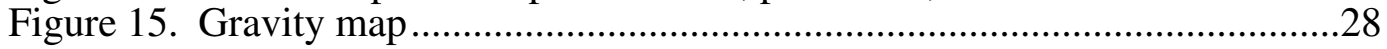




\section{INTRODUCTION}

This report summarizes the acquisition, data processing, and preliminary interpretation of a high-resolution aeromagnetic and radiometric survey near the confluence of the Big and Little Chino basins in the headwaters of the Verde River, Arizona. The U.S. Geological Survey contracted the aerial survey in 1999 in support of Task 4 of Arizona Water Protection Fund Grant 99-078. The goal of the aeromagnetic study is to improve understanding of the geologic framework as it affects groundwater flow, particularly in relation to the occurrence of springs in the upper Verde River headwaters region. Radiometric data were also collected to map surficial rocks and soils, thus aiding geologic mapping of the basin fill. Additional gravity data were collected to enhance existing coverage. This report will treat each of the geophysical methods separately. The interpretation presented here is preliminary; a more quantitative, integrated, and detailed interpretative report is planned as part of the final summary report in 2002.

\section{GEOLOGIC SETTING}

The survey covers an area of approximately $792 \mathrm{~km}^{2}\left(306 \mathrm{mi}^{2}\right)$, centered on Sullivan Lake, which is defined by State statute to be river mile 0.0 of the Verde River (Fig. 1). The survey includes the southern half of Big Chino Valley and the northern half of Little Chino Valley.

This area lies within the transition zone between the Colorado Plateau and the Basin and Range physiographic provinces. The transition zone exhibits geologic features that are common to both provinces. Regional projections indicate that Paleozoic strata are nearly continuous across the Colorado Plateau-transition zone boundary; attitudes measured for the Paleozoic rocks indicate a regional dip of $<10^{\circ}$ toward the plateau; this regional dip is interrupted by steeper dips associated with monoclines (for example, the monocline on Big Black Mesa; Fig. 2; Krieger, 1965). The zone is also characterized by a series of Tertiary and Quaternary north- and northwest-trending normal faults (Menges and Pearthree, 1983; Reynolds, 1988).

The geology of the Big Chino basin has been compiled by Ostenaa and others (1993) at 1:100,000. More detailed coverage is provided at 1:48,000 by Krieger (1965) of the Prescott and Paulden quadrangles, and the Ashfork (1967a), Picacho Butte (1967b), and Simmons (1967c) quadrangles at 1:62,500. The only digital coverage for the study area is the State of Arizona geology map, compiled by the Arizona Geological Survey (Richard and Kneale, 1998) at 1:1,000,000 and is the source of the geology shown in Figure 2. The geology of the Prescott National Forest, which includes all of the Big and Little Chino basins study area, has been mapped by Ed deWitt of the U.S. Geological Survey (written map commun., 2000) at a scale of 1:100,000. A more detailed digital coverage of the geology at scales better than presently exists would greatly enhance the geophysical interpretation efforts.

Rocks exposed in the study area consist of four main types and ages. Beginning with the oldest rocks, Precambrian igneous and metamorphic rocks form the basement complex of the area. These rocks are exposed in the mountain ranges fringing the survey area, most notably to the south in the Bradshaw Mountains and the Juniper and Santa Maria Mountains to the west (Fig. 2). Isolated Precambrian meta-sedimentary and igneous rocks are also exposed in the area (see, for example, the Precambrian outcrop $2 \mathrm{~km}$ east of Del Rio Springs, Fig. 2). The Precambrian rocks are overlain by Cambrian to Permian 
sedimentary rocks, presumably throughout much of the area, although the Paleozoic rocks have been stripped away in much of Little Chino Valley (Krieger, 1965). The thickness of the Paleozoic sequence ranges from zero in the southern part of the study area to probably as much as $850 \mathrm{~m}$ (2800 feet) in the northeast corner of Big Chino Valley (Krieger, 1965). A major unconformity and long period of erosion separate the third and fourth groups of rocks, consisting of Tertiary and Quaternary sedimentary and volcanic rocks, from the underlying Paleozoic sequence. Extensive Tertiary sedimentary rocks are exposed in both Big and Little Chino Valleys. Along the margins of Little Chino Valley, fanglomerate, mud flow deposits, and tuffaceous deposits are exposed; towards the interior of the basin, these rocks also include channel gravel, sand, silt, clay and marl. Tertiary sedimentary rocks both underlie and overlie, and in places, are interbedded with, Tertiary volcanic rocks. Tertiary volcanic rocks consist of two main lithologies, basalt and latite. Latite is extensively exposed at Sullivan Buttes. Well log data in Little Chino Valley suggest that the upper surface of the volcanic rocks ("malpais or malapais" in driller's logs and inferred to be basalt) slopes gently to the southwest from the northeast side of the basin (Krieger, 1965). The maximum thickness of the basalt penetrated in wells is $150 \mathrm{~m}(500 \mathrm{ft})$.

\section{Structural Geology and Faulting}

The most intense and complexly deformed rocks in the area are the Precambrian rocks. This deformation, which produced folds (isoclinal in the older Precambrian rocks), foliation, and faults, did not affect the Paleozoic sequence. The Paleozoic rocks generally dip less than $10^{\circ}$ to the northeast in the study area, except for the monocline on Big Black Mesa, where dips range from about $30^{\circ}$ to the northeast to near vertical in a zone of deformation less than $300 \mathrm{~m}$ (1000 ft) wide (Krieger, 1965). Structural relief on the monocline decreases to the southeast. The age of the monocline is probably Late Cretaceous to early Tertiary in age. Gravels exposed in the headwaters area of the Verde River are evidence for a northeast sloping erosion surface (Elston and Young, 1991). Remnants of these gravels exposed elsewhere suggest that this erosion surface developed before the older sequence of basalts erupted. Extensional faulting resulted in large-scale downdropping of Tertiary volcanic and sedimentary rocks in neighboring Verde Valley (east of Black Hills) about 11$8 \mathrm{Ma}$ (Elston and Young, 1991). Presumably, faulting also occurred within the study area at about the same time, but with less offset than that to the east. Much of the resultant topography was later filled in with younger basalts.

Several faults in the Transition zone show evidence of multiple ages of movement. Shoemaker and others (1978) show several northeast- and northwest-trending fault systems in northwestern Arizona that are probably Precambrian faults that have been subsequently reactivated during the Cenozoic. One of the northeast-trending fault systems, the Mesa Butte fault, projects into the study area (Fig. 2). Another fault system identified by Krieger (1965) and Shoemaker and others (1978) is the northwest-trending Big Chino fault, exposed along the southwestern edge of Big Black Mesa (Figs. 1, 2). This fault clearly shows evidence of movement as young as Quaternary just to the northwest of the study area (Menges and Pearthree, 1983). The Big Chino fault may have been responsible for the February 4, 1976 Chino Valley earthquake $\left(M_{b}=4.9\right)$, analysis of which indicated normal movement along a northwest-trending fault plane dipping $40^{\circ}$ to the southwest (EberhartPhillips and others, 1981).

Faults often serve as conduits or barriers to ground-water movement. On a regional scale, northwest -trending fractures throughout the Colorado Plateau area in northern Arizona (Shoemaker and others (1978) tend to be more open to fluid flow (Thorstenson and Beard, 
1998; L.S. Beard, oral commun., 1999). Owen-Joyce and Bell (1983, p. 20) report that well yields in the Middle Verde basin (east of the study area) are generally improved by the presence of solution cavities along fractures in the Redwall Limestone and Martin Limestone. These limestone units are exposed along the margins of the Big Chino basin and the canyon walls of the upper Verde River (Fig. 2). Thus, Wirt and Hjalmarson (2000) propose that the northwest-trending Big Chino fault, which offsets the Paleozoic limestones along the base of Big Black Mesa (Fig. 2), may serve as a conduit for ground-water exiting Big Chino Basin and supplying base flow to the upper Verde River.

\section{AEROMAGNETIC DATA, MAPS, AND DERIVATIVE PRODUCTS}

\section{About the Aeromagnetic Method}

Geologic structures (such as faults or igneous intrusions) often produce small magnetic fields that distort the main magnetic field of the Earth (Fig. 3). These distortions, called anomalies, can be detected by measuring the Earth's magnetic field on or near the surface of the ground. By analyzing magnetic measurements, geophysicists are able to learn about geologic structures, even though these structures may be buried beneath the Earth's surface (Dobrin and Savit, 1988; Blakely, 1995). Magnetic measurements are often made from airplanes (or helicopters) flown along closely spaced, parallel flight lines. Additional flight lines are flown in a perpendicular direction to aid in data processing. These measurements are then processed into a digital "aeromagnetic" map. Assisted by computer programs, the geophysicist builds a geologic interpretation from these data, incorporating geologic mapping, well information, and other available geophysical information (e.g., gravity, radiometric, electrical, seismic-reflection) where available.

\section{Magnetic Lithologies}

Volcanic rocks are the most prevalent magnetic lithology of this region, and we expect highamplitude, short-wavelength anomalies over volcanic terranes, especially in the southern part of the survey. Volcanic rocks in the area consist of (1) the Sullivan Buttes latite (24-26 Ma; also known as the andesite unit of Krieger, 1965), (2) an older sequence of basalts that is a westward continuation of the Hickey Formation of Verde Valley, and (3) a younger section of basalts, tentatively correlated with the Perkinsville Formation (also of Verde Valley). The basalts in this region typically include lava flows which individually may have a uniform direction of magnetization. Steeply dipping faults that offset subhorizontal units often produce magnetic anomalies that appear as linear trends on aeromagnetic maps (see, for example, Bath and Jahren, 1984, for the Yucca Mountain region, Nevada). The latites, on the other hand, often are extruded from volcanic plugs and thus tend to produce intense, somewhat circular magnetic anomalies (often as magnetic lows, because the latites are generally reversely polarized).

The magnetic properties of sedimentary rocks, such as the Paleozoic sequence of dolomite, limestone, and sandstone, are usually weak, such that the resulting magnetic anomalies are very small in amplitude or undetectable by airborne surveys. The Precambrian metasedimentary rocks are also essentially incapable of producing detectable magnetic anomalies. One exception is a iron-rich metachert that forms a minor lithologic constituent (Krieger, 1965; exposed south of the towns of Prescott and Prescott Valley). However, metavolcanic rocks, gabbros and some of the intrusive rocks can produce prominent 
magnetic anomalies ${ }^{1}$. Magnetic susceptility is a measure of how magnetic a rock becomes when placed in an external magnetic field and is mostly a function of the amount of magnetite in that rock. Magnetic susceptibility measurements of Precambrian metavolcanic rocks range from 2 (meta-rhyolite) to 8000 (metabasalt) $10^{-6} \mathrm{SI}$ units (Ed deWitt, written commun., 2000). Gabbros also show a high range in susceptibility, from 30 to $8000 \times 10^{-6}$ SI units $(\mathrm{N}=29)$. Granodiorites and granites show a wide range in susceptibility that decreases when considering individual plutons. For example, the Prescott granodiorite has a range of 900 to $1600 \times 10^{-6}$ units (mean of $1100 ; \mathrm{N}=6$ ). The Minnehaha granodiorite, on the other hand, is less magnetic, showing a range in susceptibility of 10 to $350 \times 10^{-6}$ units (mean of $48 ; \mathrm{N}=5$ ).

\section{Data Acquisition and Processing}

World Geoscience, Inc. (WGI) conducted the aeromagnetic survey under contract to the U.S. Geological Survey. WGI is headquartered in Ottawa, Canada, and has many years of experience in acquiring and processing aeromagnetic data. Data acquisition and processing were accomplished under guidelines established by the U.S. Geological Survey over the last several decades (see attachment by Pat Hill (United States Geological Survey, Denver, CO) to Geophysics Interpretation Plan).

The aeromagnetic data were acquired with a Cessna 208, a fixed-wing aircraft. The airborne magnetic sensor was a cesium-vapor magnetometer located at the tip of a fiberglass stinger (boom). A theoretical flight surface, based on a digital topograhic model, was computed in advance of the survey, and a real-time, differentially corrected Global Positioning System (GPS) was used during flight to maintain this theoretical surface. Flight lines were oriented east-west, spaced $150 \mathrm{~m}(.093 \mathrm{mi})$ apart, and flown at an altitude of $150 \mathrm{~m}(500 \mathrm{ft})$ above terrain, or as low as permitted by the Federal Aviation Adminstration and safety considerations. North-south control lines were spaced $3.0 \mathrm{~km}(1.83 \mathrm{mi})$ apart. Total flight distance was $5600 \mathrm{~km}$ (3460 mi). Figure 4 shows all flight path locations.

A base station magnetometer was deployed at the Ernest Love municipal airport north of the city of Prescott. A base station magnetometer measures the time-varying magnetic field and has two important functions: (1) it records the normal daily changes of the external field (diurnal variation), which are subtracted from the aeromagnetic data and (2) it records the onset and dissipation of magnetic storms. Airborne operations were interrupted if magnetic storm activity exceeded the limits established by the U.S. Geological Survey. The limits were as follows: (a) 5 nanoTeslas (nT) for monotonic changes during any 5 minute period, (b) $2 \mathrm{nT}$ for pulsations with periods of 5 minutes or less, (c) $4 \mathrm{nT}$ for pulsations with periods between 5 and 10 minutes, and (d) 8 nT for pulsations with periods between 10 and 20 minutes. Base-station instruments were cesium-vapor magnetometers, identical to the airborne sensor. Time between aircraft and base stations was synchronized with GPS time.

Preliminary data processing was performed by WGI. This included removal of diurnal fields, subtraction of the International Geomagnetic Reference Field (Blakely, 1995), navigational corrections, and adjustment of total-field values between crossings of flight lines and tie lines. A preliminary version of the completed survey was provided to the

\footnotetext{
${ }^{1}$ See Dempsey and others (1963), an aeromagnetic map that overlaps the southern margin of this higherresolution aeromagnetic survey. The 1963 map, based on a survey flown in 1947 along east-west flightlines spaced $400 \mathrm{~m}$ apart, shows significant magnetic anomalies over exposed Precambrian rocks near the city of Prescott.
} 
USGS for evaluation in December, 1999. Final data were delivered in January, 2000. Accuracy of the data is estimated to be on the order of 0.5 to $1 \mathrm{nT}$.

\section{Aeromagnetic Map and Derivative Products}

Figures 5a and 5b clearly show the improved resolution of the new, high-resolution data compared to the preexisting, regional aeromagnetic data. Color scale in these maps indicates the intensity of the Earth's magnetic field relative to a global standard (the International Geomagnetic Reference Field updated to the date of the survey). The regional digital coverage consists of east-west flightlines flown at a spacing of 1 or 3 miles for the National Uranium Resource Evaluation program (NURE, Fig. 5a). Figure 5b shows the new survey embedded into the regional digital database. As expected, volcanic regions produce distinctive magnetic anomalies, high in amplitude and short in wavelength. These anomalies are particularly evident over much of Little Chino Valley. In the preexisting regional coverage, only a broad magnetic low is present; virtually all of the individual magnetic anomalies are absent.

Surprisingly, a large magnetic high is present over the Paleozoic carbonate rocks exposed on Big Black Mesa, rocks that are weakly magnetic. Thus, the source of this anomaly is likely concealed by Paleozoic units. Krieger (1967a) shows several small exposures of Precambrian granitic rocks just northwest of the study area; these rocks are the most likely source of the aeromagnetic high. The high is truncated by the Big Chino fault on its southwestern margin (Fig. 6).

The new aeromagnetic data are of sufficient quality to permit the application of wellestablished processing and filtering techniques that emphasize subtle features. Figures 7 and 8 show the aeromagnetic data processed in ways to enhance and define near-surface sources. Figure 7 shows "residual magnetic anomalies", a technique that emphasizes shallow magnetic sources. This residual magnetic map was computed by analytically continuing the aeromagnetic data to a slightly higher surface (Blakely, 1995), in other words, mathematically transforming the data as if they were collected at a higher altitude, and subtracting that result from the original data. The anomalies that remain are commonly called residual magnetic anomalies. This method, essentially a discrete vertical derivative, emphasizes anomalies caused by shallow magnetic sources while subduing anomalies caused by deep sources. It is particularly useful in identifying shallow crustal faults that separate rocks of contrasting magnetic properties. Shallow sources produce shortwavelength anomalies, such as the anomalies present over exposed volcanic rocks.

Subtle magnetic anomalies that are not apparent in Figure 5b and 6 are accentuated in the filtered aeromagnetic data (Fig. 7). The magnetic field over the alluvial deposits of southern Big Chino Valley shows several northwest-trending low-amplitude anomalies. Because alluvium is often weakly magnetic, some of these anomalies may originate from volcanic rocks concealed beneath the surface. Other possible causes include fluvial reworking of alluvial deposits or alteration along buried fault zones.

Figure 8 shows magnetization boundaries, automatically computed from the aeromagnetic data (Blakely and Simpson, 1986). This calculation assumes that magnetic contacts are vertical; calculated positions will be shifted slightly over contacts that are not vertical. Figure 9 shows the magnetization boundaries plotted on the regional geology. Here we have used the magnetization boundaries to map the extent of the Big Chino Fault, as indicated by a lineament on the basin margin of Big Black Mesa. The magnetic data are 
consistent with Krieger's (1965) mapping that indicates displacement on the main strand of the fault decreases and splays into several strands of minor displacement towards the Verde River headwaters area. The magnetization boundaries also define structures related to buried volcanic rocks. Future work will focus on establishing the depth, thickness, and geometry of the volcanic rocks beneath Big and Little Chino Valleys.

\section{RADIOMETRIC DATA AND MAPS}

\section{About the Gamma-Ray Method}

The radiometric data indicate the apparent concentrations of potassium, uranium, and thorium in the rocks and soils at the surface. Because these elements are lithophile elements (concentrated in the Earth's silicate crust), their concentrations tend to vary for different lithologic materials. The radiometric data, therefore, provide information on the lithologic characteristics and distribution of the geologic materials.

Rocks and soils contain naturally-occurring radioactive elements. Several of those radioactive elements are present in sufficient amounts to make gamma-ray spectroscopy feasible. The isotopes best suited to gamma-ray spectroscopy are ${ }^{40} \mathrm{~K},{ }^{238} \mathrm{U}$, and ${ }^{232} \mathrm{Th}$. The decay series for ${ }^{40} \mathrm{~K}$ is relatively simple; the decay of ${ }^{40} \mathrm{~K}$ to ${ }^{40} \mathrm{Ar}$ produces gamma rays with an energy of $1.46 \mathrm{Mev}$ (million electron volts) where one electron volt is the energy of an electron that has been accelerated across a potential difference of one volt.

The decay series for ${ }^{238} \mathrm{U}$, is more complex than that of potassium, and several of the daughter isotopes have long half-lives. The longer-lived daughter isotopes allow for chemical processes to physically separate them from the parent isotope. Thus, the ${ }^{238} \mathrm{U}$ decay series may not be in secular equilibrium, meaning that the ratios of the daughter isotopes may not be constant and the estimated amount of uranium may not be correct. For more information about radioactive decay and secular equilbrium, refer to Evans (1955). For that reason the results of gamma-ray spectroscopy are designated as equivalent parts per million of uranium ( $\mathrm{ppm} \mathrm{eU}$ ). The gamma rays used for gamma-ray spectroscopy result from the decay of ${ }^{214} \mathrm{Bi}$ and the gamma ray most commonly used has an energy of $1.76 \mathrm{Mev}$.

The decay series for ${ }^{232} \mathrm{Th}$ is also complex. The possibility for disequilibrium exists and the results of gamma-ray spectroscopy are expressed as equivalent parts per million of thorium (ppm eTh). The gamma rays normally used for gamma-ray spectroscopy result from the decay of ${ }^{208} \mathrm{Tl}$ and have an energy of $2.64 \mathrm{Mev}$.

The method of gamma-ray spectroscopy uses a gamma-ray detector to measure the number of gamma rays emitted by the radioactive isotopes. Because the number of gamma rays produced is directly proportional to the total number of atoms of the respective isotopes present in the geologic materials, a properly calibrated gamma-ray spectrometer can provide direct estimates of the concentrations of the radioactive elements in the materials. The gamma-ray spectrometer can be used in a laboratory, in a vehicle, or as a portable field instrument. Laboratory instruments typically analyze small samples on the order of a kilogram or less of material. A field instrument (e.g. mounted on an aircraft) measures a much larger volume of material as illustrated in Figure 10. In theory, an airborne gammaray spectrometer measures an infinitely large and infinitely thick volume of material. Because rocks, soils, and air absorb gamma rays, the effective source is much less than 
infinite in size or thickness. For the gamma rays emitted by the decay of uranium, potassium, and thorium, the circular area measured by an airborne gamma-ray spectrometer has a diameter equal to approximately four times the altitude of the detector above the ground. The depth of measurement is on the order of $30 \mathrm{~cm}$ and does not vary for the range of altitude for this high-resolution radiometric survey. For more information on the volume of material measured by an airborne gamma-ray spectrometer, see Duval and others (1971).

\section{Radiometric Maps}

The detailed aerial survey of the study area included measurements of the magnetic field and gamma-ray spectroscopy. The gamma-ray data are calibrated and are presented in the units of concentrations of potassium (percent K), uranium (ppm eU), and thorium (ppm eTh). The absolute accuracy of the concentration values is estimated to be on the order of 20-30 percent. The comparison of values from one location to another is, however, estimated to be on the order of 5-10 percent.

In order to place the detailed survey in the context of existing regional data, the detailed survey data were compared to the data from the National Uranium Resource Evaluation (NURE) Program of the U.S. Department of Energy. The regional data have been processed by the U.S. Geological Survey to produce an internally consistent database for the conterminous United States (Duval and Riggle, 1999). The NURE profile data were compared to the detailed survey data and the detailed data were recalibrated to make the data consistent with the regional data. The maps present the detailed survey embedded in the regional data and illustrate the increased level of detail in the new data. Figures 11, 12, and 13 show the distributions of uranium, potassium, and thorium, respectively. Figure 14 is a composite-color map of uranium, potassium, and thorium with uranium as shades of red, potassium as shades of green, and thorium as shades of blue. White areas on the composite-color map are high in all of the readioactive elements and areas that are dark are low in all of the radioactive elements.

All of the radiometric maps (Fig. 11-13) show higher radioactivity associated with the Tertiary latites and with the sediments derived from them. The surficial materials on the eastern side of the Big Chino Valley are significantly lower in radioactivity and reflect the materials derived from the limestone and basalt east of the valley. The dividing line between the low radioactivity materials to the east and the higher radioactiviy materials to the west coincides approximately with the major drainage system of the valley, locally known as Big Chino Wash. This feature is remarkably straight and is approximately parallel to the Big Chino Fault. The gravity data (Fig. 15; see below) suggest that the deepest part of the basin lies to the east of this linear feature. One possible interpretation is that this feature is an indirect indication of the trailing edge of the downdropped block that formed the valley. Other features in the radiometric data will have to be carefully compared to the geologic, magnetic, and gravity data before an insightful interpretation of the data can proceed.

The uranium map shows large areas with concentrations greater than $5 \mathrm{ppm}$ eU, and we expect that these areas will have a significantly higher risk potential for indoor radon. Spencer (1986) identitied the area around Prescott at risk for radon levels exceeding limits set by the Environmental Protection Agency; Kearfott (1987) found high concentrations of radon in groundwater $(94,000 \mathrm{pCi} / \mathrm{L})$ in one home in Prescott. 


\section{GRAVITY DATA AND MAP}

As part of this project, we have compiled and reprocessed the existing gravity coverage of the region (National Geophysical Data Center, 1999) and added 119 new gravity stations using a global positioning system (GPS) to determine location and elevation. These data have been processed to provide information on subsurface density variations. The gravitational attraction at any point depends on many factors, including the latitude and elevation of the measurement, earth tides, terrain, deep masses that isostatically support the terrain, and variations in density within the Earth's crust and upper mantle. The last of these quantities is of primary interest in geologic investigations and can be obtained by calculating and removing all other quantities. The resulting field is called the isostatic residual gravity anomaly and reflects, to first order, density variations within the middle and upper crust (Simpson and others, 1986).

Big Chino Valley is characterized by a gravity low, bounded on the east by the Big Chino Fault (Fig. 15). The deepest part of the basin, as suggested by the lowest gravity value within the valley, is about $5 \mathrm{~km}$ from the northern boundary of the study area. Gravity values increase to the southeast towards Sullivan Lake. The northern part of Little Chino Valley is characterized by higher gravity values than those over Big Chino Valley, suggesting that the basin fill beneath Little Chino Valley is thin (less than $1 \mathrm{~km}$ ). South of the study area, a gravity low reflects a thick stock of Prescott granodiorite and most likely does not indicate a deep basin centered near the intersection of Highway 89 and alternate route 89 (Fig. 16; Cunion, 1985). Prescott granodiorite (and Granite Dells granite) is less dense than the some of the more mafic metavolcanic and gabbros within Precambrian basement. The significant density contrasts within Precambrian basement suggest that a simple inversion of gravity data that doesn't incorporate measurements on basement outcrops will not produce a realistic model of basin-fill thickness. Incorporation of physical property measurements, geologic constraints, and any drill-hole or other geophysical information will be critical in developing a realistic basin model, especially for Little Chino Valley.

Another gravity feature of potential hydrologic interest is the gravity low over Williamson Valley. This gravity low is outside the immediate survey area and its southwest margin is poorly defined by gravity measurements. The gravity low may reflect either a relatively deep sedimentary basin or a low-density pluton. The deep basin interpretation is preferred because the gravity low does not extend across Precambrian outcrops exposed to the east of the gravity low.

\section{CONCLUSIONS AND RECOMMENDATIONS}

High-resolution aeromagnetic data from the Verde River headwaters reflect diverse lithologies at and below the topographic surface. These data have permitted a preliminary interpretation of faults and underlying lithologies (in particular, volcanic) that will provide new insights on the geologic framework, critical input to future hydrologic investigations.

The radiometric data clearly reflect the different lithologic materials and show patterns related to the depositional processes that will aid geologic mapping. These data could aid indirectly in characterizing recharge and infiltration properties over the study area if these properties can be tied to lithologies with distinctive gamma-ray signatures. The map of uranium concentrations show areas that may have a significantly higher risk potential for indoor and groundwater radon. 
Gravity data indicate the density distribution in the upper crust. In particular, gravity lows associated with Big Chino and Williamson Valleys indicate potentially significant accumulations of low-density basin fill. The absence of a gravity low associated with Little Chino Valley indicates that high-density rocks are shallow. More quantitative analyses of the aeromagnetic and gravity data will require two- and three-dimensional modeling. Digital geologic coverages at a scale of 1:100,000 are needed before more detailed geophysical interpretations and modeling, especially depth-to-basement calculations using a 3dimensional inversion of gravity data, can proceed.

\section{ACKNOWLEDGMENTS}

We would like to thank the Arizona Water Protection Fund Commission for financial support (Arizona Water Protection Fund Grant 99-078). We are very grateful to the Salt River Project for the use of their helicopter for field reconnaissance and checking. Tom Hildenbrand (U.S. Geological Survey, Menlo Park, CA), Betsy Woodhouse and Nick Melcher (U.S. Geological Survey, Tucson, AZ), and Frank Corkhill (Arizona Department of Water Resources) provided helpful reviews. 


\section{REFERENCES}

Bath, G.D., and Jahren, C.E., 1984, Interpretations of magnetic anomalies at a potential repository site located in the Yucca Mountain area, Nevada Test Site: U.S. Geological Survey Open-File Report 82-536, 27 p.

Blakely, R.J., 1995, Potential Theory in Gravity and Magnetic Applications: Cambridge University Press, $441 \mathrm{p}$.

Blakely, R.J., and Simpson, R.W., 1986, Approximating edges of source bodies from magnetic or gravity anomalies: Geophysics, v. 51, p. 1494-1498.

Cunion, Edward Joseph, Jr., 1985, Analysis of gravity data from the southeastern Chino Valley, Yavapai County, Arizona: Northern Arizona University Master's thesis, $110 \mathrm{p}$.

Dempsey, W.J., Hill, M.E., and others, 1963, Aeromagnetic map of central Yavapai County, Arizona, including the Jerome mining district: U.S. Geological Survey Geophysical Investigations Map GP-402, scale 1:62,500.

Dobrin, M.B., and Savit, C.H., 1988, Introduction to Geophysical Prospecting: McGrawHill Book Company, 867 p.

Duval, J. S., Cook, B., and Adams, J. A. S., 1971, A study of the circle of investigation of an airborne gamma-ray spectrometer: Journal of Geophysical Research, v. 76, p. 84668470.

Duval, J.S. and Riggle, F.E., 1999, Profiles of gamma-ray and magnetic data from aerial surveys over the conterminous United States: U.S. Geological Survey Digital Data Series DDS-31, Release 2, 3 CD-ROM.

Eberhart-Phillips, D., Richardson, R.M., Sbar, M.L., and Herrmann, R.B., 1981, Analysis of the 4 February 1976 Chino Valley, Arizona, earthquake: Bulletin of Seismological Society of America, v. 71, p. 787-801.

Elston, D. and Young, 1991, Cretaceous-Eocene (Laramide) landscape development and Oligocene-Pliocene drainage reorganization of Transition Zone and Colorado Plateau: Journal of Geophysical Research, v. 96, no. B7, p. 12,389-12,406.

Evans, R.D., 1955, The Atomic Nucleus: McGraw-Hill Book Company, New York, 972 p.

Kearfott, K.J., 1987, Preliminary experience with ${ }^{222} \mathrm{Rn}$ gas in Arizona homes: Arizona State University Department of Electrical and Computer Engineering unpublished manuscript, $30 \mathrm{p}$.

Krieger, M.H., 1965, Geology of the Prescott and Paulden quadrangles, Arizona: U.S. Geological Survey Professional Paper 467, 127 p.

Krieger, M.H., 1967a, Reconnaisance geologic map of the Ashfork quadrangle, Yavapai and Coconino counties, Arizona: U.S. Geological Survey Miscellaneous Geologic Investigations Map I-499, scale 1:62,500.

Krieger, M.H., 1967b, Reconaissance geologic map of the Picacho Butte quadrangle, Yavapai and Coconino counties, Arizona: U.S. Geological Survey Miscellaneous Investigations Map I-500, scale 1:62,500.

Krieger, M.H., 1967c, Reconaissance geologic map of the Simmons quadrangle, Yavapai and Coconino counties, Arizona: U.S. Geological Survey Miscellaneous Investigations Map I-503, scale 1:62,500.

Menges, C.M., and Pearthree, P.A., 1983, Map of neotectonic (latest Pliocene-Quaternary) deformation in Arizona: Arizona Bureau of Geology and Mineral Technology, OpenFile Report 83-22, 48 p.

National Geophysical Data Center, 1999, Land and Marine Gravity CD-ROMS, compiled by David Dater, Dan Metzger, and Allen Hittelman, Boulder, CO. 
Ostenaa, D.A., Schimschal, U.S., King, C.E., Wright, J.W., Furgerson, R.B., Harrel, H.C., and Throner, R.H., 1993, Big Chino Valley groundwater study: Geologic framework investigations: Bureau of Reclamation, Denver, CO, $31 \mathrm{p}$.

Owens-Joyce, S.J., and Bell, C.K., 1983, Appraisal of water resources in the Upper Verde River area, Yavapai and Coconino Counties, Arizona: Arizona Department of Water Resources Bulletin 2,219 p.

Reynolds, S.J., 1988, Geologic map of Arizona: Arizona Geological Survey Map 26, scale 1:1,000,000.

Richard, S.M., and Kneale, S.M. (eds.), 1998, Geologic map of Arizona, GIS database: Arc/INFO export file (.e00) format, 2 disks, 10 p.

Shoemaker, E.M., Squires, R.L., and Abrams, M.J., 1978, Bright Angel and Mesa Butte fault systems of northern Arizona in Cenozoic Tectonics and Regional Geophysics of the Western Cordillera, Smith, R.B., and Eaton, G.P., eds.: Geological Society of America Memoir 152, p. 341-367.

Simpson, R.W., Jachens, R.C., Blakely, R.J., and Saltus, R.W., 1986, A new isostatic residual gravity map of the conterminous United States with a discussion on the significance of isostatic residual anomalies: Journal of Geophysical Research, v. 91, p. 8348-8372.

Spencer, J., 1986, Radon gas: a geologic hazard: Arizona Bureau of Geology and Mineral Technology Fieldnotes, v. 16, no. 4, p. 1-6.

Thorstenson, D.J., and Beard, L.S., 1998, Geology and fracture analysis of Camp Navajo, Arizona Army National Guard, Arizona: U.S. Geological Survey Open-File Report 98$242,42 \mathrm{p}$.

Wirt, Laurie, and Hjalmarson, H.W., 2000, Sources of springs supplying base flow to the Verde River headquarters, Yavapai County, Arizona: U.S. Geological Survey Open-File Report 99-0378, online release (http://greenwood.cr.usgs.gov/pub/open-file-reports/ofr99-0378), 54 p. 